\title{
Effect of NPK Fertilization on the Yield and Mineral Element Content of an Established All-grass
}

\author{
P. RAGÁLYI and I. KÁDÁR \\ Research Institute for Soil Science and Agricultural Chemistry (RISSAC) of the Hun- \\ garian Academy of Sciences, Budapest
}

\section{Introduction}

As VOISIN (1965) stated: "Mineral fertilizers are one of the most important of the discoveries of modern chemistry. Well applied they maintain and even raise soil fertility, increase crop yields, and improve the feeding value of agricultural produce. Without mineral fertilizers agriculture would never have been able to quadruple its yields in fifty years and thus earn its place as one of the principal factors in the higher standard of living of civilized countries."

If unwisely used, however, this marvellous tool can become greatly dangerous, by destroying soil fertility, reducing yields and impairing the feeding value of agricultural products, seriously and adversely affecting both animal and human health. Grass alone requires high rates of $\mathrm{N}$ in order to maximize production or to equal yields of grass-legume combinations. In New Zealand (Dow et al., 1980) up to 600 $\mathrm{lb}$ N/acre were required on grass pasture to equal the yield of grass-clover pasture receiving no $\mathrm{N}$ fertilizer. $\mathrm{N}$ over-fertilization at the same time leads to elevated nitrate content in feed or forage, which is toxic to animals. The critical range starts from $0.25 \% \mathrm{NO}_{3}-\mathrm{N}$ in D.M. for forage, where it is the only source of feed (TUCKER et al., 1961; CHAPMAN, 1966; BARCSÁK, 2004).

The application of $\mathrm{K}$ may considerably increase responses to $\mathrm{N}$ or $\mathrm{P}$ fertilizers when a progressive depletion of soil $\mathrm{K}$ occurs. Although grasses have a greater ability to extract $\mathrm{K}$ or $\mathrm{P}$ from the soil than many other crops, restrictions of growth caused by deficiencies in these elements are not uncommon in Hungary, particularly when high yields are obtained with high $\mathrm{N}$ levels and the herbage is regularly cut and removed rather than grazed. This appears mainly on sandy soils poor in $\mathrm{K}$ (ANTAL et al., 1966).

The long-term effect of N, P and K fertilizers on soil and crop is still not well understood. As a consequence of dressings of $\mathrm{P}$ fertilizers available $\mathrm{Zn}$ "disappears" from the soil. The effect is marked when the soil is relatively low in available $\mathrm{Zn}$ and the crop is susceptible to $\mathrm{Zn}$ deficiency, as in the case of corn. This effect of $\mathrm{P}$ is cumulative. At present, therefore, in traditional maize-growing regions $\mathrm{Zn}$ defi-

Correspondence to: PÉTER RAGÁLYI, Research Institute for Soil Science and Agricultural Chemistry of the Hungarian Academy of Sciences, H-1022 Budapest, Herman Ottó út 15. Hungary.E-mail: ragalyi@rissac.hu 
ciency is becoming more frequent following decades of heavy and often excessive application of P (KÁDÁR, 1992; KÁDÁR et al., 2000).

The antagonistic effect of $\mathrm{K}$ on the uptake of $\mathrm{Ca}, \mathrm{Mg}, \mathrm{Na}$, B etc. elements has been recognized for many decades. The synergetic effects of $\mathrm{N}$ on the element uptake of the main major nutrients are also well known (FINCK, 1982; GEISLER, 1988). The interactions among $\mathrm{N} \times \mathrm{P}, \mathrm{N} \times \mathrm{K}$ and $\mathrm{P} \times \mathrm{K}$ supply levels, however, are not well understood, their effect on yield and element uptake has not been revealed yet. This type of field study needs a complicated research program with a large number of plots. The present work aimed to evaluate the effect of different N, P and K supply levels and their combinations on the development, yield and mineral composition of an established all-grass sward in the $28^{\text {th }}$ year of a long-term fertilization trial set up on a calcareous chernozem soil. Details of this experiment were summarized earlier by KÁDÁR (2005a,b).

\section{Material and Methods}

The calcareous chernozem soil of the growing site contained around 3\% humus, $3-5 \% \mathrm{CaCO}_{3}, 20-22 \%$ clay in the ploughed layer and was originally supplied moderately well with available $\mathrm{K}, \mathrm{Mg}, \mathrm{Mn}, \mathrm{Cu}$ and poorly with $\mathrm{P}$ and $\mathrm{Zn}$. The trial included $4 \mathrm{~N} \times 4 \mathrm{P} \times 4 \mathrm{~K}=64$ treatments in 2 replications, giving a total of 128 plots. The applied fertilizers were Ca-ammonium nitrate, superphosphate and potassium chloride. The area was drought sensitive with the groundwater table at a depth of 13-15 $\mathrm{m}$ and negative water balance of about $100 \mathrm{~mm} / \mathrm{yr}$. The grass was established on 21 September, 2000. Treatments and the soluble PK contents of the soil's ploughed layer are given in Table 1.

During the thirty years of the experiment $0-9000 \mathrm{~kg} \mathrm{~N}, 0-4500 \mathrm{~kg} \mathrm{P}_{2} \mathrm{O}_{5}$ and 0 $7500 \mathrm{~kg} \mathrm{~K} \mathrm{~K}_{2} \mathrm{O}$ nutrients were applied per hectare. $\mathrm{N}$ doses were divided into two halves, one was applied in autumn and the other in spring. The experimental plots represent low, moderate, high and very high supply levels and all of their combina-

Table 1

Treatments and their effects on the soluble PK content in the ploughed layer of the calcareous chernozem soil

\begin{tabular}{|c|c|c|c|c|c|c|}
\hline \multirow{2}{*}{$\begin{array}{c}\text { Fertilization and } \\
\text { soil analysis }\end{array}$} & \multicolumn{4}{|c|}{ Treatments or fertilization levels } & \multirow{2}{*}{$\mathrm{LSD}_{5 \%}$} & \multirow{2}{*}{ Mean } \\
\hline & 0 & 1 & 2 & 3 & & \\
\hline \multicolumn{7}{|c|}{ Applied amount of fertilizer } \\
\hline $\mathrm{N} \mathrm{kg} / \mathrm{ha} / \mathrm{yr}$ & 0 & 100 & 200 & 300 & - & 150 \\
\hline $\mathrm{N} \mathrm{kg} / \mathrm{ha} / 30$ yrs & 0 & 3000 & 6000 & 9000 & - & 4500 \\
\hline $\mathrm{P}_{2} \mathrm{O}_{5} \mathrm{~kg} / \mathrm{ha} / 30 \mathrm{yrs}$ & 0 & 1500 & 3000 & 4500 & - & 2250 \\
\hline $\mathrm{K}_{2} \mathrm{O} \mathrm{kg} / \mathrm{ha} / 30 \mathrm{yrs}$ & 0 & 2500 & 5000 & 7500 & - & 3750 \\
\hline \multicolumn{7}{|c|}{ Ammonium lactate soluble $P$ and K content of soil (EGNÉR et al., 1960) } \\
\hline $\mathrm{AL}-\mathrm{P}_{2} \mathrm{O}_{5}, \mathrm{mg} / \mathrm{kg}$ & 66 & 153 & 333 & 542 & 42 & 274 \\
\hline $\mathrm{AL}-\mathrm{K}_{2} \mathrm{O}, \mathrm{mg} / \mathrm{kg}$ & 135 & 193 & 279 & 390 & 32 & 249 \\
\hline
\end{tabular}


tions, which may possibly be found elsewhere in arable fields or are probable to develop in the future. Until 2000 several arable crops were grown in free crop rotations. In 2001-2003 grass was grown on the whole experimental area. The mixture of 8 grass species (Meadow fescue (Festuca pratensis), Tall fescue (Festuca arundinacea), Perennial ryegrass (Lolium perenne), Agropyron (Agropyron cristatum), Red fescue (Festuca rubra), Timothy (Phleum pratense), Reed canarygrass (Phalaris arundinacea), Cocksfoot (Dactylis glomerata) was sown in autumn 2000. The dominant species was the meadow fescue with a $25 \%$ application rate.

The grass herbage had a very favourable wet year in 2001 with more than 700 $\mathrm{mm}$ rainfall during the total vegetation period and resulted in 2 cuts. Cuts were made before the flowering stage of meadow fescue. Composite plant samples from 20 subsamples per plot, as well as soil composite samples from the ploughed layer out of 20 cores per plot were taken at harvest time for laboratory analyses.

Plant samples were dried, milled and analyzed for 20-25 elements with cc. $\mathrm{HNO}_{3}+$ cc. $\mathrm{H}_{2} \mathrm{O}_{2}$ digestion and using ICP technique. After drying and milling of the soil samples, their $\mathrm{NH}_{4}$-acetate+EDTA soluble element contents were determined with the LAKANEN and ERVIÖ (1971) method, as well as their $\mathrm{NH}_{4}$-lactate soluble PK content according to EGNER et al. (1960). The layout and method of the trial was published elsewhere (KÁDÁR, 2005a).

\section{Results and Discussion}

The $1^{\text {st }}$ cut took place on 23 May, 2001. The effect of $\mathrm{N}$ was moderate in the $1^{\text {st }}$ cut, giving around $2 \mathrm{t} / \mathrm{ha}$ hay surpluses on the average, and the maximum yield responses were obtained in the $\mathrm{N}_{1}(100 \mathrm{~kg} \mathrm{~N} / \mathrm{ha} / \mathrm{yr})$ treatment. The yield of the $2^{\text {nd }}$ cut (9 October, 2001) showed increased $\mathrm{N}$ responses, the yields were basically determined only by $\mathrm{N}$ fertilization. The highest hay surpluses were obtained in the $\mathrm{N}_{3}$ $(300 \mathrm{~kg} \mathrm{~N} / \mathrm{ha} / \mathrm{yr})$ treatment, making out about $3 \mathrm{t} / \mathrm{h}$. There was a 4 -fold increment in hay yield due to the applied N (Table 2).

The ,moderate” supply levels $\left(135 \mathrm{mg} / \mathrm{kg}\right.$ AL- $\mathrm{K}_{2} \mathrm{O}$ and $153 \mathrm{mg} / \mathrm{kg}$ AL- $\left.\mathrm{P}_{2} \mathrm{O}_{5}\right)$ basically satisfied the $\mathrm{P}$ and $\mathrm{K}$ demands of grass. An increasing trend was observable, however, in hay yields with the higher P supply levels. Without a satisfactory $\mathrm{P}$ supply the efficiency of $\mathrm{N}$ fertilization is much lower and vice versa. $\mathrm{N}, \mathrm{P}$ or $\mathrm{K}$ over-fertilization did not cause a significant depression, though the higher P levels reduced yield on the $\mathrm{N}$ control plots in both the $1^{\text {st }}$ and $2^{\text {nd }}$ cut. There were no $\mathrm{P}$ responses any more at the later harvesting date (9 October) even on the $\mathrm{P}_{1}$ (low) supply level, with $66 \mathrm{mg} / \mathrm{kg} \mathrm{AL}-\mathrm{P}_{2} \mathrm{O}_{5}$ value (Table 2).

The differences are much more enhanced considering the unfertilized control plots $\left(\mathrm{N}_{0} \mathrm{P}_{0} \mathrm{~K}_{0}\right)$ and the balanced rising NPK treatments. In the $1^{\text {st }}$ and $2^{\text {nd }}$ cuts the hay yield of the $\mathrm{N}_{0} \mathrm{P}_{0} \mathrm{~K}_{0}$ plots was 1.7 and $1.2 \mathrm{t} / \mathrm{ha}$, while the highest $\left(\mathrm{N}_{3} \mathrm{P}_{3} \mathrm{~K}_{3}\right)$ treatment gave $8.8 \mathrm{t} / \mathrm{ha}$ and $4.2 \mathrm{t} / \mathrm{ha}$, respectively. NPK fertilization increased the air-dry hay yield from $3 \mathrm{t} /$ ha to $13 \mathrm{t} / \mathrm{ha}\left(1^{\text {st }}+2^{\text {nd }}\right.$ cuts together $)$ in the $1^{\text {st }}$ year of the trial (Table 3). 
Table 2

Effect of $\mathrm{N} \times \mathrm{P}$ supply levels on the air-dry hay yield in $2001, \mathrm{t} / \mathrm{ha}$

\begin{tabular}{|c|c|c|c|c|c|c|}
\hline \multirow{2}{*}{$\begin{array}{c}\mathrm{AL}-\mathrm{P}_{2} \mathrm{O}_{5} \\
\mathrm{mg} / \mathrm{kg}\end{array}$} & \multicolumn{4}{|c|}{ Yearly $\mathrm{N}$ fertilization rates, $\mathrm{kg} \mathrm{N} / \mathrm{ha} / \mathrm{yr}$} & \multirow{2}{*}{$\mathrm{LSD}_{5 \%}$} & \multirow{2}{*}{ Means } \\
\hline & 0 & 100 & 200 & 300 & & \\
\hline \multicolumn{7}{|c|}{$1^{\text {st }}$ cut (23 May) } \\
\hline 66 & 3.3 & 3.9 & 3.8 & 4.8 & & 4.0 \\
\hline 153 & 5.5 & 7.2 & 7.6 & 6.9 & 1.0 & 6.8 \\
\hline 333 & 5.8 & 7.9 & 7.4 & 7.4 & & 7.1 \\
\hline 542 & 4.9 & 8.1 & 7.9 & 8.1 & & 7.2 \\
\hline Mean & 4.9 & 6.8 & 6.7 & 6.8 & 0.5 & 6.3 \\
\hline \multicolumn{7}{|c|}{$2^{\text {nd }}$ cut (9 October) } \\
\hline 66 & 1.4 & 2.7 & 3.5 & 3.6 & & 2.8 \\
\hline 153 & 0.8 & 2.1 & 3.5 & 4.0 & 0.4 & 2.6 \\
\hline 333 & 1.0 & 2.3 & 3.4 & 4.0 & & 2.7 \\
\hline 542 & 0.9 & 2.1 & 3.4 & 3.9 & & 2.7 \\
\hline Mean & 1.0 & 2.3 & 3.4 & 3.9 & 0.2 & 2.7 \\
\hline
\end{tabular}

Note: Data are given as a mean of $\mathrm{K}$ treatments

The optimum $\mathrm{N}$ content in the hay, leading to maximum yield, amounted to $2 \%$ and $2.5-3.0 \%$ in the $1^{\text {st }}$ and $2^{\text {nd }}$ cut. As a consequence of the applied $\mathrm{N}$ the air-dry content decreased from $33 \%$ to $31 \%$ in the $1^{\text {st }}$ cut, and from $27 \%$ to $21 \%$ in the $2^{\text {nd }}$. In the $1^{\text {st }}$ cut hay the optimum $\mathrm{K}$ content was around $2 \%$ and more, where the highest hay yields were obtained. Here the K/P ratio was about 10 and the $\mathrm{N} / \mathrm{K}$ ratio around 1.0. It should be emphasized that these optima are or may be valid for grass species mixture without legume crops, similar to these described conditions, and for the $1^{\text {st }}$ cut hay.

As a function of $\mathrm{N}$ fertilization the element content of hay in the $1^{\text {st }}$ cut usually increased, except for $\mathrm{Al}$ and Mo, which showed dilution effects. The rise in element concentration was $25-50 \%$ for $\mathrm{K}, \mathrm{Ca}, \mathrm{Mg}, \mathrm{Mn}, \mathrm{P}, \mathrm{Sr}, \mathrm{B}$ and $\mathrm{Ni} ; 60-70 \%$ for $\mathrm{S}$ and $\mathrm{Co}$, two-fold for $\mathrm{N}$ and $\mathrm{Cu}$; five-fold for $\mathrm{NO}_{3}-\mathrm{N}$ and $\mathrm{Na}$ as compared to the $\mathrm{N}$ control (Table 4).

Table 3

Effect of different NPK supply levels on the air-dry hay yield of the $1^{\text {st }}$ and $2^{\text {nd }}$ cut, $t /$ ha

\begin{tabular}{|c|c|c|c|c|c|c|}
\hline \multirow{2}{*}{ Date of cut } & \multicolumn{5}{|c|}{$\mathrm{NPK}$ supply levels or combinations } & \multirow{2}{*}{ LSD $_{5 \%}$} \\
\cline { 2 - 6 } & $\mathrm{N}_{0} \mathrm{P}_{0} \mathrm{~K}_{0}$ & $\mathrm{~N}_{1} \mathrm{P}_{0} \mathrm{~K}_{0}$ & $\mathrm{~N}_{1} \mathrm{P}_{1} \mathrm{~K}_{1}$ & $\mathrm{~N}_{2} \mathrm{P}_{2} \mathrm{~K}_{2}$ & $\mathrm{~N}_{3} \mathrm{P}_{3} \mathrm{~K}_{3}$ & \\
\hline 23 May, 2001 & 1.7 & 3.5 & 7.8 & 7.9 & 8.8 & 2.0 \\
9 Oct., 2001 & 1.2 & 2.0 & 2.6 & 3.7 & 4.2 & 0.8 \\
Together & 3.0 & 5.5 & 10.4 & 11.6 & 13.0 & 2.4 \\
\hline
\end{tabular}

Note: For applied fertilizer amounts: See Table 1 
Table 4

Effect of $\mathrm{N}$ fertilization on the mineral element content of the air-dry hay on 23 May, 2001

\begin{tabular}{|c|c|c|c|c|c|c|c|}
\hline \multirow{2}{*}{\multicolumn{2}{|c|}{$\begin{array}{l}\text { Measured elements } \\
\text { and units }\end{array}$}} & \multicolumn{4}{|c|}{ N-fertilization, $\mathrm{kg} \mathrm{N} / \mathrm{ha} / \mathrm{yr}$} & \multirow{3}{*}{$\frac{\mathrm{LSD}_{5 \%}}{0.09}$} & \multirow{3}{*}{$\begin{array}{l}\text { Mean } \\
2.22\end{array}$} \\
\hline & & \multirow{2}{*}{$\begin{array}{c}0 \\
1.86\end{array}$} & \multirow{2}{*}{$\begin{array}{c}100 \\
2.37\end{array}$} & \multirow{2}{*}{$\begin{array}{l}200 \\
2.26\end{array}$} & \multirow{2}{*}{$\begin{array}{l}300 \\
2.38\end{array}$} & & \\
\hline $\mathrm{K}$ & $\%$ & & & & & & \\
\hline $\mathrm{N}$ & $\%$ & 1.10 & 1.87 & 2.09 & 2.39 & 0.16 & 1.86 \\
\hline $\mathrm{Ca}$ & $\%$ & 0.48 & 0.56 & 0.58 & 0.62 & 0.03 & 0.56 \\
\hline $\mathrm{S}$ & $\%$ & 0.15 & 0.25 & 0.26 & 0.26 & 0.01 & 0.23 \\
\hline $\mathrm{P}$ & $\%$ & 0.17 & 0.22 & 0.22 & 0.23 & 0.01 & 0.21 \\
\hline $\mathrm{Mg}$ & $\%$ & 0.12 & 0.17 & 0.18 & 0.18 & 0.01 & 0.16 \\
\hline $\mathrm{NO}_{3}-\mathrm{N}$ & $\%$ & 0.06 & 0.10 & 0.22 & 0.34 & 0.03 & 0.18 \\
\hline $\mathrm{Na}$ & $\mathrm{mg} / \mathrm{kg}$ & 109 & 488 & 574 & 535 & 62 & 426 \\
\hline $\mathrm{Mn}$ & $\mathrm{mg} / \mathrm{kg}$ & 83 & 106 & 114 & 118 & 5 & 105 \\
\hline $\mathrm{Al}$ & $\mathrm{mg} / \mathrm{kg}$ & 102 & 93 & 80 & 78 & 23 & 88 \\
\hline $\mathrm{Sr}$ & $\mathrm{mg} / \mathrm{kg}$ & 13 & 16 & 16 & 17 & 1 & 15 \\
\hline B & $\mathrm{mg} / \mathrm{kg}$ & 4.4 & 5.4 & 5.3 & 5.4 & 0.4 & 5.1 \\
\hline $\mathrm{Cu}$ & $\mathrm{mg} / \mathrm{kg}$ & 2.1 & 3.8 & 4.4 & 4.7 & 0.3 & 3.8 \\
\hline $\mathrm{Ni}$ & $\mathrm{mg} / \mathrm{kg}$ & 0.90 & 1.01 & 1.10 & 1.12 & 0.16 & 1.03 \\
\hline Mo & $\mathrm{mg} / \mathrm{kg}$ & 0.21 & 0.20 & 0.18 & 0.16 & 0.02 & 0.19 \\
\hline $\mathrm{Co}$ & $\mathrm{mg} / \mathrm{kg}$ & 0.05 & 0.07 & 0.07 & 0.08 & 0.02 & 0.07 \\
\hline
\end{tabular}

Note: $\mathrm{As}, \mathrm{Hg}, \mathrm{Cd}, \mathrm{Pb}$ and $\mathrm{Se}$ are usually below the $0.1 \mathrm{mg} / \mathrm{kg}$ detection limit. Data are given as means of PK treatments

As it can be seen in Table 5, P fertilization stimulated the uptake of $\mathrm{Mn}$ and $\mathrm{Mg}$ by $10-20 \% ; \mathrm{S}, \mathrm{NO}_{3}-\mathrm{N}$ and $\mathrm{Co}$ by $40-50 \%, \mathrm{Na}$ and $\mathrm{Sr}$ by $60-70 \%$, P by $90 \%$; while it inhibited the uptake of $\mathrm{Zn}$ and $\mathrm{Co}$ by $20-40 \%$, $\mathrm{Al}$ and $\mathrm{Fe}$ by $50-60 \%$, Mo by $70 \%$ in comparison to the $\mathrm{P}$ control. The reduced Fe content has no considerable effect on grass quality, but the decline in $\mathrm{Zn}$ content in fodder may cause disturbances in some protein synthesis. The optimal $\mathrm{P} / \mathrm{Zn}$ rate is assumed to be between 50 and 150 (KÁDÁR, 1992). The $\mathrm{P} / \mathrm{Zn}$ ratio in the $\mathrm{P}$ control soil showed optimal values of 118 , while in the soil with high $\mathrm{P}$ supply this ratio was 278 , indicating $\mathrm{Zn}$ deficiency.

$\mathrm{K}$ fertilization had a marked effect on the mineral element composition of the $1^{\text {st }}$ cut. So, due to the rising $\mathrm{K}$ levels $\mathrm{K}, \mathrm{Ba}$ and $\mathrm{N}$ increased in the hay, while the uptake of all other measured elements was depressed. It is worth mentioning that not only the uptake of metal cations was hindered, but also that of B and Mo, which are generally in anion form in the soil solution (Table 6).

The soil $\mathrm{P} \times \mathrm{K}$ levels show negative interactions with the $\mathrm{Fe}, \mathrm{Al}$, Mo and $\mathrm{Cr}$ content of the $1^{\text {st }}$ cut hay (Table 7). The applied PK fertilizers were not sources of these elements, so the changes in element concentrations were induced. In the case of the highest $\mathrm{PK}$ levels $\mathrm{Fe}, \mathrm{Al}$ and $\mathrm{Cr}$ contents dropped to $1 / 3$ of the control values. The hay's Mo content, however, decreased by an order of magnitude, thus PK prevalence is probable to induce Mo deficiency in this soil. This phenomenon cannot be revealed by soil analysis but by plant analysis with diagnostic purposes (BERGMAN, 1992). Data in Table 7 are given as means of $\mathrm{N}$ treatments. 
Table 5

Effect of soil P supply on the mineral element content of the air-dry hay on 23 May, 2001

\begin{tabular}{|lc|c|c|c|c|c|c|}
\hline \multicolumn{2}{|c|}{$\begin{array}{c}\text { Measured elements } \\
\text { and units }\end{array}$} & \multicolumn{2}{|c|}{ Ammonium lactate soluble $\mathrm{P}_{2} \mathrm{O}_{5}, \mathrm{mg} / \mathrm{kg}$} & \multirow{2}{*}{ LSD $_{5 \%}$} & \multirow{2}{*}{ Mean } \\
\cline { 2 - 5 } & 66 & 153 & 333 & 542 & & \\
$\mathrm{~S}$ & $\%$ & 0.17 & 0.24 & 0.26 & 0.25 & 0.01 & 0.23 \\
$\mathrm{P}$ & $\%$ & 0.13 & 0.20 & 0.24 & 0.25 & 0.01 & 0.21 \\
$\mathrm{Mg}$ & $\%$ & 0.14 & 0.16 & 0.17 & 0.17 & 0.01 & 0.16 \\
$\mathrm{NO}_{3}-\mathrm{N}$ & $\%$ & 0.14 & 0.20 & 0.19 & 0.20 & 0.03 & 0.18 \\
$\mathrm{Na}$ & $\mathrm{mg} / \mathrm{kg}$ & 298 & 448 & 486 & 474 & 62 & 426 \\
$\mathrm{Mn}$ & $\mathrm{mg} / \mathrm{kg}$ & 95 & 111 & 112 & 103 & 5 & 105 \\
$\mathrm{Al}$ & $\mathrm{mg} / \mathrm{kg}$ & 147 & 65 & 73 & 67 & 23 & 88 \\
$\mathrm{Fe}$ & $\mathrm{mg} / \mathrm{kg}$ & 204 & 119 & 119 & 107 & 38 & 137 \\
$\mathrm{Sr}$ & $\mathrm{mg} / \mathrm{kg}$ & 11 & 14 & 17 & 19 & 1 & 15 \\
$\mathrm{Zn}$ & $\mathrm{mg} / \mathrm{kg}$ & 11 & 9 & 9 & 9 & 1 & 10 \\
$\mathrm{Ni}$ & $\mathrm{mg} / \mathrm{kg}$ & 0.87 & 1.03 & 1.10 & 1.13 & 0.16 & 1.03 \\
$\mathrm{Mo}$ & $\mathrm{mg} / \mathrm{kg}$ & 0.32 & 0.16 & 0.14 & 0.12 & 0.02 & 0.19 \\
$\mathrm{Co}$ & $\mathrm{mg} / \mathrm{kg}$ & 0.08 & 0.07 & 0.06 & 0.05 & 0.02 & 0.07 \\
\hline
\end{tabular}

Note: $\mathrm{As}, \mathrm{Hg}, \mathrm{Cd}, \mathrm{Pb}$ and $\mathrm{Se}$ are below the $0.1 \mathrm{mg} / \mathrm{kg}$ detection limit. Data are given as means of NK treatments

Table 6

Effect of soil K supply on the element content of the air-dry hay on 23 May, 2001

\begin{tabular}{|lc|c|c|c|c|c|c|}
\hline \multicolumn{2}{|c|}{$\begin{array}{c}\text { Measured elements } \\
\text { and units }\end{array}$} & \multicolumn{2}{|c|}{ Ammonium lactate soluble $\mathrm{K}_{2} \mathrm{O}, \mathrm{mg} / \mathrm{kg}$} & \multirow{2}{*}{ LSD $_{5 \%}$} & \multirow{2}{*}{ Mean } \\
\cline { 2 - 6 } & 135 & 193 & 279 & 390 & & \\
$\mathrm{~K}$ & $\%$ & 1.89 & 2.18 & 2.35 & 2.45 & 0.09 & 2.22 \\
$\mathrm{~N}$ & $\%$ & 1.76 & 1.79 & 1.86 & 2.04 & 0.16 & 1.86 \\
$\mathrm{Ca}$ & $\%$ & 0.62 & 0.56 & 0.54 & 0.52 & 0.03 & 0.56 \\
$\mathrm{Mg}$ & $\%$ & 0.19 & 0.16 & 0.15 & 0.15 & 0.01 & 0.16 \\
$\mathrm{Al}$ & $\mathrm{mg} / \mathrm{kg}$ & 103 & 87 & 91 & 71 & 23 & 88 \\
$\mathrm{Fe}$ & $\mathrm{mg} / \mathrm{kg}$ & 163 & 137 & 134 & 115 & 38 & 137 \\
$\mathrm{Sr}$ & $\mathrm{mg} / \mathrm{kg}$ & 16 & 15 & 15 & 14 & 1 & 15 \\
$\mathrm{Ba}$ & $\mathrm{mg} / \mathrm{kg}$ & 6.3 & 6.7 & 8.3 & 9.0 & 0.6 & 7.6 \\
$\mathrm{~B}$ & $\mathrm{mg} / \mathrm{kg}$ & 6.0 & 5.1 & 4.8 & 4.6 & 0.4 & 5.1 \\
$\mathrm{Cu}$ & $\mathrm{mg} / \mathrm{kg}$ & 4.0 & 3.6 & 3.8 & 3.6 & 0.3 & 3.8 \\
$\mathrm{Ni}$ & $\mathrm{mg} / \mathrm{kg}$ & 1.30 & 1.01 & 1.14 & 0.68 & 0.16 & 1.03 \\
$\mathrm{Mo}$ & $\mathrm{mg} / \mathrm{kg}$ & 0.23 & 0.21 & 0.19 & 0.12 & 0.02 & 0.19 \\
$\mathrm{Co}$ & $\mathrm{mg} / \mathrm{kg}$ & 0.08 & 0.06 & 0.06 & 0.06 & 0.02 & 0.07 \\
\hline
\end{tabular}

Note: $\mathrm{As}, \mathrm{Hg}, \mathrm{Cd}, \mathrm{Pb}$ and $\mathrm{Se}$ are below the $0.1 \mathrm{mg} / \mathrm{kg}$ detection limit. Data are given as means of NP treatments 
Table 7

Effect of $\mathrm{P} \times \mathrm{K}$ supply levels on Fe, Al, Mo, Cr contents of air-dry hay on 23 May, 2001

\begin{tabular}{|c|c|c|c|c|c|c|}
\hline \multirow{2}{*}{$\begin{array}{c}\mathrm{AL}-\mathrm{K}_{2} \mathrm{O} \\
\mathrm{mg} / \mathrm{kg}\end{array}$} & \multicolumn{4}{|c|}{ Ammonium lactate soluble (AL) $\mathrm{P}_{2} \mathrm{O}_{5}, \mathrm{mg} / \mathrm{kg}$} & \multirow{2}{*}{$\mathrm{LSD}_{5 \%}$} & \multirow{2}{*}{ Mean } \\
\hline & 66 & 153 & 333 & 542 & & \\
\hline \multicolumn{7}{|c|}{$\mathrm{Fe}, \mathrm{mg} / \mathrm{kg}$} \\
\hline 135 & 307 & 119 & 127 & 101 & \multirow{3}{*}{76} & 163 \\
\hline 193 & 175 & 149 & 115 & 107 & & 137 \\
\hline 279 & 197 & 104 & 118 & 116 & & 134 \\
\hline 390 & 140 & 103 & 114 & 105 & \multirow[b]{2}{*}{38} & 115 \\
\hline Mean & 204 & 119 & 119 & 107 & & 137 \\
\hline \multicolumn{7}{|c|}{$\mathrm{Al}, \mathrm{mg} / \mathrm{kg}$} \\
\hline 135 & 206 & 72 & 73 & 63 & \multirow{3}{*}{46} & 103 \\
\hline 193 & 139 & 71 & 72 & 67 & & 87 \\
\hline 279 & 148 & 59 & 76 & 80 & & 91 \\
\hline 390 & 97 & 60 & 69 & 60 & \multirow[b]{2}{*}{23} & 71 \\
\hline Mean & 147 & 65 & 73 & 67 & & 88 \\
\hline \multicolumn{7}{|c|}{ Mo, $\mathrm{mg} / \mathrm{kg}$} \\
\hline 135 & 0.44 & 0.18 & 0.15 & 0.15 & \multirow{3}{*}{0.04} & 0.23 \\
\hline 193 & 0.30 & 0.16 & 0.17 & 0.15 & & 0.19 \\
\hline 279 & 0.34 & 0.20 & 0.15 & 0.15 & & 0.21 \\
\hline 390 & 0.24 & 0.09 & 0.09 & 0.05 & \multirow[b]{2}{*}{0.02} & 0.12 \\
\hline Mean & 0.33 & 0.16 & 0.14 & 0.12 & & 0.19 \\
\hline \multicolumn{7}{|c|}{$\mathrm{Cr}, \mathrm{mg} / \mathrm{kg}$} \\
\hline 135 & 0.33 & 0.14 & 0.17 & 0.10 & \multirow{4}{*}{0.08} & 0.19 \\
\hline 193 & 0.20 & 0.14 & 0.16 & 0.17 & & 0.17 \\
\hline 279 & 0.20 & 0.12 & 0.13 & 0.14 & & 0.15 \\
\hline 390 & 0.14 & 0.12 & 0.14 & 0.13 & & 0.13 \\
\hline Mean & 0.22 & 0.13 & 0.15 & 0.13 & 0.04 & 0.16 \\
\hline
\end{tabular}

Note: data are given as means of $\mathrm{N}$ treatments

According to Table 8 , the $\mathrm{N} \times \mathrm{K}$ interactions resulted in a dramatic increase in the $\mathrm{N}$ content of the $1^{\text {st }}$ cut hay from $0.96 \%$ measured in the NK control up to $2.72 \%$ in the highest $\mathrm{NK}$ level. In the case of $\mathrm{K}$ the increase was from 1.71 to $2.79 \%$. $\mathrm{N}$ fertilization had a stimulating, while $\mathrm{K}$ fertilization a depressing effect on the $\mathrm{Ca}, \mathrm{Mg}$ and $\mathrm{Zn}$ uptake in hay. For assessing the nutrient status of crops information is also needed about the ratios of measured elements in plant tissues. As a function of $\mathrm{N} \times \mathrm{K}$ supply the ratios of $\mathrm{K} / \mathrm{Ca}$ varied between $5-7$, that of $\mathrm{K} / \mathrm{Mg}$ between $10-18$, that of $\mathrm{K} / \mathrm{Ni}$ was around $10-40$ thousand.

The $\mathrm{N} \times \mathrm{K}$ levels have extreme effects on the $\mathrm{Na}$ content of hay (Table 9). Generally, the $\mathrm{Na}$ content of hay was increased several times by $\mathrm{N}$ fertilization, while $\mathrm{K}$ fertilization caused a similar rate decrease, counterbalancing each others influence. Indeed, the source of $\mathrm{Na}$ was the $\mathrm{K}$ fertilizer in soil. However, the $\mathrm{K}-\mathrm{Na}$ antagonism and $\mathrm{N}-\mathrm{Na}$ synergism were of crucial importance for plant uptake. 
Table 8

Effect of $\mathrm{N} \times \mathrm{K}$ supply levels on the $\mathrm{N}, \mathrm{K}, \mathrm{Ca}, \mathrm{Mg}$ and $\mathrm{Ni}$ contents of the air-dry hay on 23 May, 2001

\begin{tabular}{|c|c|c|c|c|c|c|}
\hline \multirow{2}{*}{$\begin{array}{c}\mathrm{AL}-\mathrm{K}_{2} \mathrm{O} \\
\mathrm{mg} / \mathrm{kg}\end{array}$} & \multicolumn{4}{|c|}{$\mathrm{N}$ fertilization, $\mathrm{kg} \mathrm{N} / \mathrm{ha} / \mathrm{yr}$} & \multirow{2}{*}{$\mathrm{LSD}_{5 \%}$} & \multirow{2}{*}{ Mean } \\
\hline & 0 & 100 & 200 & 300 & & \\
\hline \multicolumn{7}{|c|}{$N \%$} \\
\hline 135 & 0.96 & 1.80 & 2.00 & 2.30 & & 1.76 \\
\hline 193 & 1.10 & 1.84 & 1.94 & 2.28 & 0.31 & 1.79 \\
\hline 279 & 1.14 & 1.90 & 2.15 & 2.26 & & 1.86 \\
\hline 390 & 1.21 & 1.94 & 2.29 & 2.72 & & 2.04 \\
\hline Mean & 1.10 & 1.87 & 2.09 & 2.39 & 0.16 & 1.86 \\
\hline \multicolumn{7}{|c|}{$K \%$} \\
\hline 135 & 1.71 & 2.03 & 1.82 & 2.02 & & 1.89 \\
\hline 193 & 1.81 & 2.44 & 2.31 & 2.15 & 0.19 & 2.18 \\
\hline 279 & 2.00 & 2.49 & 2.35 & 2.56 & & 2.35 \\
\hline 390 & 1.94 & 2.52 & 2.55 & 2.79 & & 2.45 \\
\hline Mean & 1.86 & 2.37 & 2.26 & 2.38 & 0.09 & 2.22 \\
\hline \multicolumn{7}{|c|}{$\mathrm{Ca} \%$} \\
\hline 135 & 0.48 & 0.62 & 0.66 & 0.70 & & 0.62 \\
\hline 193 & 0.46 & 0.59 & 0.59 & 0.59 & 0.06 & 0.56 \\
\hline 279 & 0.49 & 0.52 & 0.55 & 0.59 & & 0.54 \\
\hline 390 & 0.46 & 0.52 & 0.52 & 0.59 & & 0.52 \\
\hline Mean & 0.48 & 0.56 & 0.58 & 062 & 0.03 & 0.56 \\
\hline \multicolumn{7}{|c|}{$M g \%$} \\
\hline 135 & 0.12 & 0.20 & 0.21 & 0.21 & & 0.19 \\
\hline 193 & 0.12 & 0.18 & 0.19 & 0.18 & 0.02 & 0.16 \\
\hline 279 & 0.12 & 0.16 & 0.17 & 0.17 & & 0.15 \\
\hline 390 & 0.11 & 0.15 & 0.16 & 0.17 & & 0.15 \\
\hline Mean & 0.12 & 0.17 & 0.18 & 0.18 & 0.01 & 0.16 \\
\hline \multicolumn{7}{|c|}{$\mathrm{Ni}, \mathrm{mg} / \mathrm{kg}$} \\
\hline 135 & 1.23 & 1.30 & 1.29 & 1.38 & & 1.30 \\
\hline 193 & 0.82 & 1.10 & 1.13 & 1.01 & 0.32 & 1.01 \\
\hline 279 & 0.80 & 1.05 & 1.19 & 1.31 & & 1.08 \\
\hline 390 & 0.56 & 0.60 & 0.80 & 0.76 & & 0.68 \\
\hline Mean & 0.85 & 1.01 & 1.10 & 1.12 & 0.16 & 1.02 \\
\hline
\end{tabular}

Note: Ammonium lactate soluble $\mathrm{K}_{2} \mathrm{O}(\mathrm{mg} / \mathrm{kg})$ in the ploughed layer. Data are given as means of $\mathrm{P}$ treatments.

The hay of the $2^{\text {nd }}$ cut contained about $20 \%$ more N, K, Ca, Mg and Na, $40 \%$ more $\mathrm{Cu}, 70-80 \%$ more $\mathrm{S}$ and $\mathrm{Mn}, 90 \%$ more $\mathrm{Fe}$ and $\mathrm{P}, 140 \%$ more $\mathrm{Al}$ and nearly 5 -times more Mo. There was no change in the $\mathrm{B}$ content, while $\mathrm{NO}_{3}-\mathrm{N}$ dropped by $40 \%$. Contents of $\mathrm{As}, \mathrm{Hg}, \mathrm{Cd}, \mathrm{Pb}$ and $\mathrm{Se}$ were usually below the $0.1 \mathrm{mg} / \mathrm{kg}$ detection limit, but in the $2^{\text {nd }}$ cut hay $\mathrm{Cd}$ was measurable in the aging plant herbage. The $\mathrm{Cu} / \mathrm{Mo}$ ratio was 2.6 in the $\mathrm{N}$ control soil, while in the soil heavily fertilized with $\mathrm{N}$ 
Table 9

Effect of soil $\mathrm{N} \times \mathrm{K}$ supply on the $\mathrm{Na}$ content of the air-dry hay in the $1^{\text {st }}$ and $2^{\text {nd }}$ cut, $\mathrm{mg} / \mathrm{kg}$

\begin{tabular}{|c|c|c|c|c|c|c|}
\hline \multirow{2}{*}{$\begin{array}{l}\text { N supply, } \\
\mathrm{kg} \mathrm{N} / \mathrm{ha} / \mathrm{yr}\end{array}$} & \multicolumn{4}{|c|}{ Ammonium lactate soluble $\mathrm{K}_{2} \mathrm{O}, \mathrm{mg} / \mathrm{kg}$} & \multirow{2}{*}{$\mathrm{LSD}_{5 \%}$} & \multirow{2}{*}{ Mean } \\
\hline & 153 & 193 & 279 & 390 & & \\
\hline \multicolumn{7}{|c|}{23 May, 2001} \\
\hline 0 & 115 & 114 & 111 & 96 & & 109 \\
\hline 100 & 447 & 512 & 471 & 521 & 124 & 488 \\
\hline 200 & 554 & 531 & 557 & 652 & & 574 \\
\hline 300 & 600 & 480 & 490 & 569 & & 535 \\
\hline Mean & 429 & 409 & 407 & 459 & 62 & 426 \\
\hline \multicolumn{7}{|c|}{9 October, 2001} \\
\hline 0 & 100 & 105 & 69 & 56 & & 82 \\
\hline 100 & 702 & 252 & 292 & 332 & 260 & 395 \\
\hline 200 & 1189 & 596 & 524 & 682 & & 748 \\
\hline 300 & 1198 & 708 & 656 & 807 & & 842 \\
\hline Mean & 798 & 415 & 385 & 469 & 130 & 517 \\
\hline
\end{tabular}

its value was 7.8. The $\mathrm{P} / \mathrm{Zn}$ ratio indicated an optimal value of 150 in the $\mathrm{P}$ control soil, while its value was 269 in the soil over-fertilized with P. So, the P-induced $\mathrm{Zn}$ deficiency was also provable in the hay of the $2^{\text {nd }}$ cut, while the $\mathrm{Cu}$-induced $\mathrm{Mo}$ deficiency disappeared.

\section{Summary}

The grass herbage had a very favourable wet year in 2001 with more than 700 $\mathrm{mm}$ rainfall during the total vegetation period. The hay yield of the unfertilized control plots was 1.7 and $1.2 \mathrm{t} / \mathrm{ha}$ in the $1^{\text {st }}$ and $2^{\text {nd }}$ cut, while the $\mathrm{N}_{3} \mathrm{P}_{3} \mathrm{~K}_{3}$ treatment produced 8.8 and $4.2 \mathrm{t} / \mathrm{ha}$ yields, resp. NPK fertilization increased the air-dry hay yield from 3 to $13 \mathrm{t} / \mathrm{ha}\left(1^{\text {st }}+2^{\text {nd }}\right.$ cuts together $)$. The $\mathrm{N}$ requirement of the young grass was moderate, while the $\mathrm{P}$ response significant in the $1^{\text {st }}$ cut. The optimum $P$ supply was $150 \mathrm{mg} / \mathrm{kg}$ ammonium lactate soluble $\mathrm{AL}-\mathrm{P}_{2} \mathrm{O}_{5}$ in the ploughed layer. No K responses were observed on the soil with $135 \mathrm{mg} / \mathrm{kg} \mathrm{AL}-\mathrm{K}_{2} \mathrm{O}$ values. There were no $\mathrm{P}$ responses by the $2^{\text {nd }}$ cut even on the soil with low P supply ( $66 \mathrm{mg} / \mathrm{kg} \mathrm{AL}-\mathrm{P}_{2} \mathrm{O}_{5}$ value), while the applied $\mathrm{N}$ caused a 4-fold increase in hay yield. The optimum $\mathrm{N}$ content in the hay, leading to maximum yield, amounted to $2 \%$ in the $1^{\text {st }}$ cut and $2.5-3.0 \%$ in the $2^{\text {nd }}$. The applied $\mathrm{N}$ decreased the air-dry content of the $1^{\text {st }}$ cut from $33 \%$ to $31 \%$, and that of the $2^{\text {nd }}$ cut from $27 \%$ to $21 \%$.

Summarizing the above, it can be stated that long-term fertilization can drastically change (in some cases with an order of magnitude) the concentrations and ratios of elements built in hay through synergetic or antagonistic effects. In the hay of the $1^{\text {st }}$ cut, for example, the minima-maxima contents of measured elements varied in air-dry hay as follows: $\mathrm{N} 0.90-3.02$, Ca $0.4-0.7$, S $0.14-0.32$, P 0.12 
0.30, Mg 0.10-0.24\%; Na 70-700, Fe 100-288, Al 45-250, Mn 71-130, Sr 10-22, Zn 7-14, Ba 6-11, B 3.6-8.1, Ni 0.3-1.6, Cr 0.1-0.4, Mo 0.04-0.44, Co 0.04-0.12 $\mathrm{mg} / \mathrm{kg}$.

Key words: NPK fertilization, established all-grass, hay yield, mineral element content of hay yield

\section{References}

Antal, J., Egerszegi, S. \& Penyigei, D., 1966. Plant Production on Sand. (In Hungarian) Mezögazdasági Kiadó. Budapest.

BARCSÁK, Z., 2004. Bio Grass Management. (In Hungarian) Mezőgazda Kiadó. Budapest.

BergmanN, W., 1992. Nutritional Disorders of Plants. Gustav Fischer Verlag. JenaStuttgart-New York.

Chapman, H. D. (Ed.), 1966. Diagnostic Criteria for Plants and Soils. Quality Printing Co., Inc. Riverside, CA.

Dow, A. I. et al., 1980. Effects of $\mathrm{N}$ fertilization on yield, $\mathrm{N}$ recovery, nutrient content and quality of three irrigated pasture grasses. Bulletin 0893. College of Agriculture, Research Centre. Washington State University. USA.

EgNÉR, H., RIEHM, H. \& DOMINGO, W. R., 1960. Untersuchungen über die chemische Bodenanalyse als Grundlage für die Beurteilung des Nährstoffzustandes der Böden. II. K. Lantbr. Högsk. Ann. 26. 199-215.

FINCK, A., 1982. Fertilizers and Fertilization. Verlag Chemie. Deerfield Beach, FloridaBasel.

GEISLER, G., 1988. Pflanzenbau. 2. Auflage. Paul Parey. Berlin-Hamburg.

KÁDÁR, I., 1992. Principles and Methods of Plant Nutrition. (In Hungarian) MTA Talajtani és Agrokémiai Kutató Intézete. Budapest.

KÁDÁR, I., 2005a. Effect of fertilization on the yield and $\mathrm{N}$ uptake of an established allgrass sward. 1. (In Hungarian) Gyepgazd. Közl. 2. 36-45.

KÁDÁR, I., 2005b. Effect of fertilization on the mineral element content of an established all-grass sward. 3. (In Hungarian) Gyepgazd. Közl. 2. 57-66.

KÁDÁR, I. et al., 2000. Mineral nutrition of maize (Zea mays L.) on chernozem soil I. (In Hungarian) Növénytermelés. 49. 371-388.

LAKANEN, E. \& ERVIÖ, R., 1971. A comparison of eight extractants for the determination of plant available microelements in soils. Acta Agr. Fenn. 123. 223-232.

TUCKER, J. M. et al., 1961. Nitrate Poisoning in Livestock. Circular No. 506. Calif. Agr. Exp. Sta. CA.

Voisin, A., 1965. Fertilizer Application. Soil, Plant, Animal. Crosby Lockwood. London. 